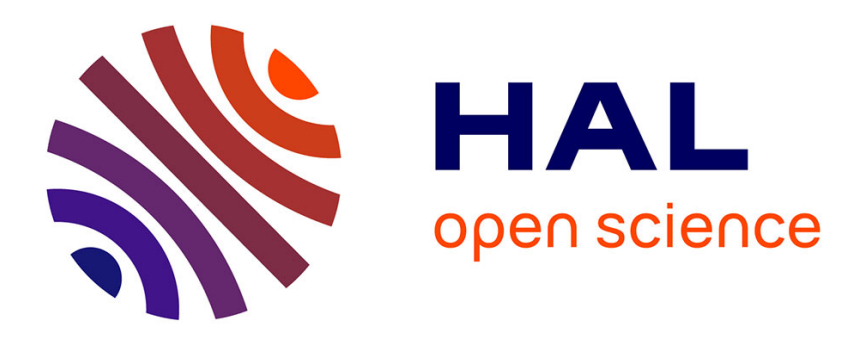

\title{
The investment development path in space
}

Alexandros Ragoussis

\section{To cite this version:}

Alexandros Ragoussis. The investment development path in space. Review of World Economics, 2011, 147 (3), pp.527-541. 10.1007/s10290-011-0089-7 . hal-00670756

\section{HAL Id: hal-00670756 https://hal.science/hal-00670756}

Submitted on 16 Feb 2012

HAL is a multi-disciplinary open access archive for the deposit and dissemination of scientific research documents, whether they are published or not. The documents may come from teaching and research institutions in France or abroad, or from public or private research centers.
L'archive ouverte pluridisciplinaire HAL, est destinée au dépôt et à la diffusion de documents scientifiques de niveau recherche, publiés ou non, émanant des établissements d'enseignement et de recherche français ou étrangers, des laboratoires publics ou privés. 


\title{
The Investment Development Path in Space
}

\author{
Alexandros Ragoussis*
}

18th January 2011

\begin{abstract}
Although spatial hypotheses are not new in the FDI literature, their examination in the dynamic context of the 'investment development path' (IDP) provides some new insights. In this paper, we examine proximity to markets at different stages of the IDP as a determinant of a country's own foreign direct investment (FDI) pattern. Our main contribution lies in the empirical estimation of the importance of spatial determinants for the emergence of inward and outward FDI. Our results support that distance to countries at higher stages up the IDP which are better integrated into the world FDI network, has a negative effect on the probability of transition from any stage of the IDP to the next. The magnitude of the impact is generally increasing in the stage of the surrounding markets.
\end{abstract}

JEL Classification: F21, F23

Keywords: Foreign Direct Investment; Investment Development Path.

*OECD Statistics Directorate, 2 rue André Pascal, 75775 Paris cedex 16, France. Email: alexandros.ragoussis@oecd.org. I wish to thank Donald Wright and Mark Melatos for detailed comments to earlier drafts, as well as participants at the Barcelona IGU Conference 2008 for helpful suggestions. The views and opinions expressed in this paper do not represent the views of the OECD nor of its member countries. 


\section{Introduction}

The inward and outward foreign direct investment (FDI) positions of a country are known to be associated with the country's level of economic development. More specifically, as economic development proceeds, inward FDI stocks initially rise. Over time, learning-by-doing allows outward FDI to emerge. In the long run, inward and outward stocks tend to balance. The 'investment development path' (IDP) is a popular theory developed to describe this dynamic phenomenon (Dunning, 1980, 1981, 1986; Dunning and Narula, 1996). In the stylized form of the path, countries progress through different stages first in response to the changing conditions that alter the country's attractiveness to foreign investors, and second in response to a gradual upgrading of domestic firmspecific advantages. The empirical work on the IDP that has so far appeared in the literature is mainly descriptive and includes non-parametric tests of hypotheses on the determinants of the process. Formal empirical testing of the IDP hypothesis has been developed in Durán and Ubeda (2005) although the explanatory variables proposed in that model deviate from the standard framework used to explain FDI activity in international economics. Several other researchers in international business have applied the concept to analyses of specific cases of countries (see Dunning and Narula, 1996, or more recently Gorynia et al., 2009). In all these empirical models, the hypothesis of spatial relationships as a determinant of a country's evolution through the IDP is absent. In this paper we aim to extend the empirical work on the IDP to incorporate 'space'. Although the literature on FDI determinants is very large, the analysis of investment flows in a spatial context is still in its infancy (see Blonigen et al., 2007; Ekholm et al., 2007; Blonigen et al., 2008). We seek to move one step further in that direction by associating a country's geographical location with its role as a host and parent country of FDI. In order to do so, we add spatial lags as explanatory variables into a benchmark empirical model aiming to explain transitions in the IDP. The main contribution of our paper lies in the empirical estimation of the importance of spatial determinants for what could be 
called the 'extensive-margin of FDI'; that is, the emergence of inward and outward FDI. Our main conclusion is that proximity to countries at higher stages up the IDP which are better integrated into the world FDI network, has a positive effect on transitions from any stage of the IDP to the next. More specically, we show that proximity to markets generating FDI increases the probability of a country becoming a host, while proximity to these countries and to countries receiving inward FDI increases the probability of receiving FDI. The results are consistent with a number of static spatial hypotheses in the literature. The rest of the paper is structured as follows: Section 2 reviews the IDP hypothesis stage by stage, using findings from the international economics literature, and augments the scenario with spatial considerations. The analysis points at a number of spatial hypotheses to be empirically tested. Section 3 elaborates the data and the empirical model we use to test the hypotheses. The paper concludes with the results and a brief discussion of the findings.

\section{The IDP hypothesis}

Dunning (1980) first described the IDP as a sequence of four distinct stages, which he later extended to five (Dunning 1986; Dunning and Narula, 1996). Stage 1 of the path corresponds to initial phase where a country is considered unattractive to foreign investors. The market is controlled by domestic firms that cannot afford foreign expansion, and thus only serve the domestic market. At the following stage 2, inward FDI stocks initially rise and the country develops its role as a host of FDI. Progress through stage 2 comes in response to changes in the market's 'location-specific advantages'. Over time, learning-by-doing allows outward FDI to emerge and the country enters in stage 3 of the IDP. A gradual upgrading of domestic 'firm-specific advantages' allows expansion into foreign markets. The initial growth of outward FDI is usually high enough for outward stocks to outweight inward stocks (stage 4). The country finally reaches a long-run equilibrium at stage 5 of the IDP, where inward and outward stocks tend to balance. 
The international economics literature has provided a number of explanations for the mechanisms motivating inward and outward FDI. In this section we review transitions to stages 2 and 3 , first with specific reference to that literature. We then augment the scenarios with spatial considerations, forming the main testable hypotheses of this paper.

\subsection{Transition to an FDI Host}

\subsubsection{Determinants}

Countries progress through stage 2 in response to changes in the market's 'locationspecific advantages'. One could include in those advantages factors such as the country's market size, or the prices of factors of production. More specifically, if the market experiences unusually high growth, foreign firms serving the domestic economy through exports seek to produce inside the country or acquire domestic firms, in order to replace increasing total transportation costs with the fixed cost of producing domestically. According to the dominant theoretical explanation for horizontal FDI, the "proximityconcentration trade-off' is the main driver of the increase in inward FDI (see Markusen, 1984; Horstmann and Markusen, 1992). Capital flows could also be attracted to best serve the foreign home market through vertical FDI. In standard models of vertical FDI factors of production are assumed to be cheaper in the host country than at home. Hence the trade-off is between the lower costs of producing abroad and the need to pay trade costs to bring the goods back home. Helpmann (1984), Braconier et al. (2005) and Hanson et al. (2005) all offer treatments of vertical FDI in formal theoretical and empirical models, while Markusen (2002) develops an integrated treatment of both horizontal and vertical investment in his 'knowledge-capital model of the multinational entreprise (MNE)'. 


\subsubsection{Spatial factors}

The spatial consideration we bring in at this stage is simple. Other than a country's own characteristics, is transition to stage 2 influenced by proximity to countries at various other stages of the IDP? If such an effect exists, then proximity to countries at which stage of the IDP could have the most signicant impact? Countries at higher stages up the IDP (3, 4 and 5) are generators of FDI. Geographical distance is moreover known to be one of the most important obstacles to $\mathrm{FDI}^{1}$. Therefore, given a country's idiosyncratic characteristics, proximity to countries at stages 3,4 and 5 of the IDP is expected to have a positive impact on transition to stage 2 , that is, transition out of unattractiveness to foreign investors. We refer to that motivating factor for FDI as the 'domestic market potential'. The higher up the chain the neighboring countries are, the more important outward flows are relative to inward, and we expect the impact of 'domestic market potential' to be stronger into the host. On the other hand, countries at the first two stages of the IDP do not generate FDI. Proximity to markets at stage 2 of the IDP could explain increased inward FDI activity to a host country due to a "neighboring market potential' effect. More specically, assume two spatially close markets at stage 2 of the IDP that could both potentially receive FDI from a third location. The foreign firm from the third country has four options: They can choose to (i) export to both locations, or (ii) invest in both locations, or (iii) invest in one location and export in the other one or (iv) produce output for both markets in one of the two locations (the socalled 'export-platform') and then ship a part of the output produced at the 'platform' to the neighboring market. The latter strategy generates an additional source of profits

\footnotetext{
${ }^{1}$ Looking at the determinants of US foreign affiliate sales in levels, Carr et al. (2001) and Markusen and Maskus (2002) estimate a distance parameter of -1.5. It is however noteworthy that in a standard 'proximity-concentration' framework the impact of distance on FDI flows should be positive. Because of the trade-substituting role of horizontal FDI, as well as the established association of distance with trade costs (see Bergstrand, 1985), distance is expected to reduce trade flows and strengthen the incentive for investment. The opposite empirical evidence could be seen as an indication for vertical instead of horizontal multinational activity. Alternatively, it could indicate that foreign plant set-up costs are positively correlated with distance so that a negative distance parameter could also arise in the case of horizontal multinationals (Markusen and Venables, 2000).
} 
from FDI by saving either on transportation costs (otherwise born from the origin), or by saving on set-up costs for FDI in the second country. Ultimately, some additional investment in the host country could be attracted because of proximity to a market at stage 2 of the IDP. The importance of export-platform FDI was documented recently in Hanson et al. (2005), and further elaborated theoretically in Ekholm et al. (2007).

'Vertical specialisation' could also justify a positive impact of proximity to markets at stage 2 of the IDP on a country's inward FDI flows. When firms exploit efficiency advantages at multiple stages of the production process by linking sequentially facilities in several countries, then FDI in one location could positively impact on the probability of the emergence of inward flows in its neighboring markets too. Finally, countries at stage 1 of the process are unattractive to foreign investors or exporters. These countries do not generate FDI either; therefore, proximity to them is not expected to have an impact on transition from stage 1 to 2 .

\subsection{Transition to an FDI Parent}

\subsubsection{Determinants}

Countries progress through stage 3 in response to the changing conditions of the firms' 'ownership-specific advantages', such as their intangible assets and productivity. A gradual upgrading of domestic 'firm-specific advantages' could be explained by a number of factors. Domestic firms can benefit from the presence of foreign production activity in the host country by imitating production techniques, or alternatively by acquiring the human capital of foreign-owned firms. In exploring the spillover effects of FDI there has been a rich literature, both theoretical and empirical since the 1990s. The evidence on this positive externality is mixed so far (see Javorcik, 2004; Görg and Greenaway, 2004, for an exhaustive review). Nevertheless, the literature offers alternative explanations for the reduction in the productivity gap between domestic and foreign firms. For instance, growth in the home country can increase both the size and the productivity of 
domestic firms. The key to this scenario is the assumption that large firm size facilitates the development of firm-specific assets which produce a dynamic effect on the expansion of MNEs. This result had been established empirically in the 1980s (Caves, 1974; Blomström and Lipsey, 1991).

\subsubsection{Spatial factors}

The spatial hypotheses that we can incorporate regarding the emergence of outward FDI can first be identified by symmetry to those motivating inward FDI. More specifically, proximity to markets receiving FDI (that is, at stages 2 and above) should have an impact on the probability of transition to stage 3; that is the emergence of outward FDI. We refer to this motivating factor as the 'foreign market potential'. It is noteworthy that the 'foreign market potential' is identical to the 'domestic market potential' effect discussed previously as a determinant for transition to stage 2 . The only difference is that now we are considering it from the symmetric point of view of the parent country. Since neighboring countries higher up the chain host firms with productivity advantages relative to the rest of the world, the 'foreign market potential' effect on outward FDI should be decreasing with the stage targeted markets are in. High competition as a barrier to entry in the potential host country explains that intensity decline. In addition, we have already established that a country's probability of receiving FDI is expected to increase with proximity to markets at all stages of the IDP except stage 1 (see $\S 2.1$ ). A higher productivity of foreign establishments in the host country could potentially be translated into productivity gains for domestic firms. An upgrading of domestic firmspecific advantages would increase in its turn the probability of outward FDI from the domestic market; that is, transition to stage 3 of the IDP. We refer to this motivating factor as the 'spillovers effect'. Tables 1 and 2 outline the hypotheses on how proximity to countries at different stages of the IDP (rows) impacts on the probability of a country's transition to stage 2 and stage 3 , respectively; that is the emergence of inward and 
outward FDI. For instance, in the first column of Table 1 we read that according to the 'domestic market potential' hypothesis, proximity to markets at stages 3 , 4, and 5 of the IDP contributes positively to the probability of the emergence of inward FDI. The contribution is stronger, the higher up the IDP neighboring markets are in.

\subsection{Transition to the final stages of the IDP}

According to the stylised version of the IDP, in stage 4 outward FDI stock continues to rise faster than does inward FDI and the country's 'net outward position' (that is, the difference between outward and inward stocks) becomes positive. The distinguishing feature of stage 4 is that outward FDI flows exceed inward flows in the domestic market. We assume that the same factors motivating the emergence could equally impact positively on the expansion of outward FDI. Transition from stage 3 to 4 can hence be explained within the same theoretical framework, by an even stronger productivity gain for domestic firms and an even stronger impact of neighboring countries on the probability of the emergence of outward FDI. The 4th stage, as well as the 5th and final stage, are typical of the few most developed countries. In this study we do not diversify hypotheses regarding transition to the 4 th and transition to the 5th stage of the IDP. First, because any relevant hypothesis for the last stage of the IDP is very hard to assess empirically. Transition to the 5th stage has only been observed in very few economies of the world. Second, because idiosyncratic factors such as cultural barriers to the establishment of foreign firms, or the structure of production may well impede the balance between inward and outward FDI in the long-run, making that distinction irrelevant. 
Table 1: Empirical predictions for the probability of transition from stage 1 to 2

\begin{tabular}{c|c|c}
\hline & \multicolumn{2}{|c}{ Hypotheses } \\
\hline $\begin{array}{c}\text { Proximity to countries at } \\
\text { Stage }\end{array}$ & $\begin{array}{c}\text { Domestic } \\
\text { Market Potential }\end{array}$ & $\begin{array}{c}\text { neighboring } \\
\text { Market Potential }\end{array}$ \\
\hline 1 & & + \\
\hline 2 & & \\
\hline 3 & + & \\
\hline $4-5$ & + & \\
\hline
\end{tabular}

Table 2: Empirical predictions for the probability of transition from stage 2 to 3

\begin{tabular}{c|c|c}
\hline & \multicolumn{2}{|c}{ Hypotheses } \\
\hline \hline $\begin{array}{c}\text { Proximity to countries at } \\
\text { Stage }\end{array}$ & $\begin{array}{c}\text { Foreign } \\
\text { Market Potential }\end{array}$ & Spillovers effect \\
\hline 1 & & + \\
\hline 2 & + & + \\
\hline 3 & + & + \\
\hline $4-5$ & + & + \\
\hline
\end{tabular}


"C:/Users/Alex/Documents/Sydney Uni PC files/Graphs Empirical paper/Spain sep".emf

Figure 1: Spain: Transition to stage 3 (1986), and to stage 4 (1997).

\section{The empirical model}

\subsection{Identifying the IDP}

With the exception of few countries, data on FDI flows are very volatile. It is often difficult to establish a long run upward or downward trend in the data. In order to circumvent this problem, we applied the Hodrick-Prescott filter (Hodrick and Prescott, 1997) to flows of inward and outward FDI, a method widely used by macroeconomists to obtain a smooth estimate of the trend component of a series. The inward and outward FDI series were plotted in separate curves for each country along with their long-run trends. The country's 'net outward position', that is, the difference between outward and inward stocks is the standard measure used in the literature to empirically identify the IDP (see Dunning, 1980, 1981, 1986; Dunning and Narula, 1996; Durán and Ubeda, 2005). However, if both inward and outward flows depend on the size of the market, then so does their difference. We choose the ratio of inward to outward flows of each country as a measure of the relative inward and outward investment position which is independent of the size of the market. We plot the ratio in a logarithmic scale, along with its long-run trend. More details on the data used for this application can be found in the Appendix. ${ }^{2}$ After plotting the series, the separate inward and outward curves are used to identify the point in time when a country starts becoming attractive to foreign investors. Our analysis focuses on changes in the slope of the curves; not primarily in the values they represent. The criteria for the classification of countries into different stages are summarised in Tables 3 and 4 . An illustration of the separate curves we use for the case of Spain can be found in Figure 1. Out of the 6,373 observations treated in the application, 874 were classified as 'inconclusive' because of missing values or various

\footnotetext{
${ }^{2}$ The data set and full set of graphs for the 187 countries of the analysis is available upon request.
} 
Table 3: Diagrams used for the identification of transitions in the IDP

\begin{tabular}{|c|c|}
\hline Transitions through stages & Diagrams used for identification \\
\hline \hline $1-2$ & Separate Curves (Inward Flow/GDP\%) \\
\hline $2-3$ & Separate Curves (Outward Flow/GDP\%) \\
\hline $3-4$ & Flows Ratio Curve (log Inw/Out flow) \\
\hline $4-5$ & Flows Ratio Curve (log Inw/Out flow) \\
\hline
\end{tabular}

Table 4: Criteria for the identification of transitions in the IDP

\begin{tabular}{|c|c|c|c|c|}
\hline & \multicolumn{2}{|c|}{ Separate Curves (Flow/GDP\%) } & Flows Ratio Curve (log Inw/Out flow) \\
\hline Transitions through stages & Slope of the trend & Value at initial point & Slope of the trend & Value at initial point \\
& $(1)$ & $(2)$ & $(3)$ & above 2.5 \\
\hline \hline $1-2$ & positive (Inw) & above $0.5 \%$ & positive & \\
& flat (Out) & $0 \%-0.5 \%$ & negative & $0-2.5$ \\
\hline $2-3$ & positive (both) & above $0.5 \%$ & negative & below 0 \\
\hline $3-4$ & positive (both) & above $0.5 \%$ & flat & 0 \\
\hline $4-5$ & positive (both) & above $0.5 \%$ & & 0 \\
\hline
\end{tabular}

Note: Columns (2) and (4) show the criteria we use for stage identification at the starting points of the curves, where there is no indication on the slope or trend due to the absence of previous observations. 
other reasons. Overall, the units of observation classified at one of the stages of the IDP according to the criteria proposed are 5,499 out of the total number of 6,373 observations (that is, $86 \%$ of the sample). In what follows, we present the empirical model testing the theoretical predictions for factors motivating the IDP. The implications of the results and conclusions are left for the last section.

\subsection{The econometric specification}

\subsubsection{Spatial variables}

A variable representing spatial proximity of country $i$ to markets at one specific stage of the IDP is constructed as the sum of GDPs of countries at that stage, each weighted by the distance to country $i$. In our data set we observe $N$ countries for $T$ time periods. In order to calculate one spatial variable for proximity to markets at stage $v$, we introduce a set of five binary variables $s(v), v \in\{1,2,3,4,5\}$ recording whether at year $t$, country $i$ is at stage $v$ or not $\left(s_{i t}(v)=1\right.$ as opposed to $\left.s_{i t}(v)=0\right)$. We interact each stage dummy with $g_{i t}$ standing for the GDP of country $i$ at time $t$. Let $q_{i t}(v)=s_{i t}(v) g_{i t}$ and $\mathbf{q}_{\mathbf{v}}$ be the $(N \times T) \times 1$ vector containing these observations for stage $v$. Let $\mathbf{q}$ be the $(N \times T) \times 5$ matrix containing observations for all stages of the IDP. Distance $d_{i j}$ between locations $i$ and $j$ is calculated as air distance (known also by the term 'distance as the crow flies'). ${ }^{3}$ We use data on geographical latitude and longitude of capital cities provided by the Environmental Systems Research Institute (ESRI) and then construct the $(N \times N) \times 1$ spatial weighting vector $\mathbf{w}$, where each element $w_{i j}$ denotes the inverse of distance between countries $i$ and $j$, that is $w_{i j}=1 / d_{i j}$. The product of $\mathbf{w} \times \mathbf{q}_{\mathbf{v}}$ yields a $(N \times T) \times 1$ vector $\mathbf{z}_{\mathbf{v}}$ containing the sum of the sizes of markets at some specific stage

\footnotetext{
${ }^{3}$ Using geographical latitudes and longitudes of any two points on the surface of the earth we can calculate air-distance as the spherical angular difference $\Delta \hat{\sigma}$ between them multiplied by the radius $R$ of the earth. Let $\phi_{i}, \lambda_{i} ; \phi_{j}, \lambda_{j}$ be the geographical latitude and longitude of two points (a base 'standpoint' $i$ and the destination 'forepoint' $j$ ), respectively, and $\Delta \phi, \Delta \lambda$ their differences. $\Delta \hat{\sigma}$, that is the angular difference, or central angle can be constituted from the spherical law of cosines: $\Delta \hat{\sigma}=$ $\arccos \left(\cos \phi_{i} \cos \phi_{j} \cos \Delta \lambda+\sin \phi_{i} \sin \phi_{j}\right)$
} 
$v$ of the IDP, weighted by their distances to a specific location for $N$ countries and $T$ years. Each vector element $z_{i t}(v)$ stands for

$$
z_{i t}(v)=\sum_{j \neq i} \frac{q_{i t}(v)}{d_{i j}}=\sum_{j \neq i} \frac{s_{i t}(v) g_{i t}}{d_{i j}}
$$

The product can be approached as a measure of proximity to markets at some specific stage $v$ of the IDP. In particular, it represents the sum of GDPs of countries at some specific stage $v$ of the Chain as if all these markets were concentrated $1 \mathrm{~km}$ away from the capital city. Let $\mathbf{z}$ be the $(N \times T) \times 5$ matrix containing the five vectors $\mathbf{z}_{\mathbf{v}}$ for all stages of the IDP.

\subsubsection{The Model}

The empirical strategy we adopt breaks the estimation of the model into four steps. Each step corresponds to one transition in the IDP. For each estimation we use the part of the sample that is relevant to the corresponding transition, that is, only those countries classified in either of the two stages of the transition. For example, when we model the probability of transition from stage 1 to 2 we exclude all observations of countries classified in stages 3,4 , and 5 ; we create a binary dependent variable $y$ that takes the value of zero at the initial stage (that is, stage 1 in our example) and the value of one at the stage-outcome of the transition (stage 2 in our example). We then test the probability that this transition occurs $P\left(y_{i t}=1\right)$ over a set of independent variables reflecting characteristics of the country $i$ at time $t$, and a set of spatial variables measuring proximity to markets at some specific stage of the IDP. We repeat the estimation for transitions 2-3, 3-4 and 4-5. These empirical models are used to formally examine "what has changed' when a country moves from one stage to another. In our data set we observe $N$ countries for $T$ time periods. For the subsample relevant to each transition, at each observation we record whether transition has occurred or not ( $y_{i t}=1$ as opposed 
to $\left.y_{i t}=0\right)$. Let $\mathbf{y}$ denote the $(N \times T) \times 1$ vector containing these binary observations. Let $\mathbf{x}$ denote the $(N \times T) \times k$ matrix of observations on $(k-1)$ co-variates potentially explaining $\mathbf{y}$. Each variable included in $\mathbf{x}$ aims to capture the impact of a different factor motivating the IDP: GDP is used as a measure of the size of the market; imports and exports to test the trade-substituting motive for FDI predicted by the theory; trade volume measures the openness of the economy; the change in the exchange rate is used to control for the structural correlation between FDI and imports/exports required for zero balance of payments; GDP per unit of labor force as a general measure of productivity of the labor force in the country. The host market size and the productivity of domestic firms are measures theoretically founded. The profitability of FDI relative to exports depends also on the productivity of foreign firms and transportation costs (correlated to the distance of markets in the rest of the world with respect to the domestic country). Both these variables are indirectly captured by the measure of imports from the rest of the world. Moreover, since the remoteness of each country relative to the rest of the world is not a parameter changing over time, a part of its impact is captured by the fixed country effect. In this specification, we add $\mathbf{z}$ denoting the $(N \times T) \times 5$ matrix of observations on 5 co-variates, one for each stage of the IDP and model the relationship between $\mathbf{y}, \mathbf{x}$ and $\mathbf{z}$ using a unobserved effects logit equation

$$
P\left(y_{i t}=1 \mid \mathbf{x}_{\mathbf{i t}}, \alpha_{i}\right)=\frac{\exp \left(\alpha_{i}+\mathbf{x}_{\mathbf{i t}} \gamma+\mathbf{z}_{\mathbf{i t}} \rho\right)}{1+\exp \left(\alpha_{i}+\mathbf{x}_{\mathbf{i t}} \gamma+\mathbf{z}_{\mathbf{i t}} \rho\right)}, \quad i=1, \ldots, N, \quad t=1, \ldots, T
$$

Table 5 presents the results for the marginal effects of each element of $\mathbf{x}$ and $\mathbf{z}$ on the probability of a country's transition to the next stage of the IDP, which is interpretable, as opposed to the ML estimators of $\gamma$ and $\rho$ which are not. Marginal Effects are calculated at values of $\mathbf{x}_{\mathbf{i t}}$ and $\mathbf{z}_{\mathbf{i t}}$ yielding $P \simeq 0.5$, and assuming that the idiosyncratic effect equals zero. We report results for both a fixed effects (FE) and a random effects (RE) specification. According to the Hausmann test, FE is preferable at the $1 \%$ level 
for transition 1-2 with a $\chi^{2}$ statistic of 15.42 (which however is not extreme). The test yields a negative value of -12.15 for transition $2-3$, confirming that the samples used for each estimation differ significantly (43 countries remaining in the sample for FE estimation as opposed to 132 for RE), in which case we cannot compare directly the two results. The FE specification could not appropriately fit the data for transitions 3-4 and 4-5 since convergence was not achieved during the ML estimation, probably due to a flat likelihood function. Estimates of $\gamma$ and $\rho$ in the last two transitions, are only reported for a RE specification. In all cases, we focus more on the RE results since they reflect an estimation over a significantly larger number of observations.

\subsubsection{Results}

The empirical predictions are unambiguous for transitions 1-2, albeit mixed for transition 2-3. It is hence interesting to distinguish between what is supported or not by the data. Predictions for transition 1-2 are consistent with the spatial hypotheses regarding the IDP. Proximity to markets at stage 3 and above appears to have a positive impact on the probability of the emergence of inward FDI stocks in a country. More specifically, a one billion US dollar increase in the GDP of neighboring countries at stage 3 of the IDP (concentrated at a distance of $1 \mathrm{~km}$ of the capital city) is predicted to increase the probability of the country's transition to stage 2 by $21 \%$ in the FE specification and $24 \%$ in the RE specification. The sign and size of the marginal effect of variable $\mathrm{S}(2)$ reflecting proximity to markets at stage 2 of the IDP is also consistent with our discussion on the impact of export-platform and vertical specialisation strategies. Nevertheless, the variable does not appear to be significant in our estimation. Lastly, proximity to countries at stage 1 of the process appears marginally significant in the FE estimation and insignicant in the RE. Predictions for factors motivating transition to stage 3 are in principle consistent with the spatial hypotheses. Results appear to support either or both the 'foreign market potential' effect and the 'spillovers effect': proximity to countries at 
Table 5: Logit marginal effects on the probability of transition

Marginal Effects on the Probability of transition to the next stage

assuming the idiosyncratic effect $=0$ and calculated at values of $\mathbf{x}$ and $\mathbf{z}$ yielding $P \simeq 0.5$

\begin{tabular}{|c|c|c|c|c|c|c|c|c|}
\hline & \multicolumn{8}{|c|}{ Iransition tnrougn stages } \\
\hline & \multirow{2}{*}{$\begin{array}{l}\mathbf{1 - 2} \\
\mathrm{FE}\end{array}$} & \multirow{2}{*}{$\begin{array}{l}\mathbf{1 - 2} \\
\mathrm{RE}\end{array}$} & \multirow{2}{*}{$\begin{array}{l}\mathbf{2 - 3} \\
\text { FE }\end{array}$} & \multirow{2}{*}{$\begin{array}{l}\mathbf{2 - 3} \\
\mathrm{RE}\end{array}$} & \multirow{2}{*}{$\begin{array}{l}\text { 3-4 } \\
\mathrm{FE}\end{array}$} & \multirow{2}{*}{$\begin{array}{l}\text { 3-4 } \\
\mathrm{RE}\end{array}$} & \multirow{2}{*}{$\begin{array}{l}\text { 4-5 } \\
\text { FE }\end{array}$} & \multirow{2}{*}{$\begin{array}{l}\mathbf{4 - 5} \\
\mathrm{RE}\end{array}$} \\
\hline & & & & & & & & \\
\hline \multirow[t]{2}{*}{ GDP (billion US dollars) } & 0.00157 & $0.00272^{* * *}$ & $0.04965^{* * *}$ & $0.00582^{* * *}$ & - & $0.00815^{* * *}$ & - & $0.00170^{* * *}$ \\
\hline & $(0.0012)$ & $(0.0010)$ & $(0.0143)$ & $(0.0004)$ & - & $(0.0013)$ & - & $(0.0002)$ \\
\hline \multirow[t]{2}{*}{ GDP growth (\%) } & $0.00682^{* *}$ & $0.00709^{* *}$ & 0.01021 & 0.00563 & - & -0.02014 & - & $-0.10341^{*}$ \\
\hline & $(0.0030)$ & $(0.0030)$ & $(0.0089)$ & $(0.0064)$ & - & $(0.0290)$ & - & $(0.0531)$ \\
\hline \multirow[t]{2}{*}{$\Delta($ Exchange Rate $)$} & $-0.57023^{* * *}$ & $-0.56632^{* * *}$ & 0.01075 & -0.35025 & - & 0.80531 & - & $-3.08964^{* *}$ \\
\hline & $(0.1181)$ & $(0.1166)$ & $(0.3375)$ & $(0.2051)$ & - & $(0.9445)$ & - & $(1.2987)$ \\
\hline \multirow[t]{2}{*}{ Imports (\%GDP) } & $0.01308^{* * *}$ & $0.01326^{* * *}$ & $-0.01140^{*}$ & 0.00139 & - & -0.03507 & - & $-0.11151^{*}$ \\
\hline & $(0.0027)$ & $(0.0026)$ & $(0.0064)$ & $(0.0035)$ & - & $(0.0267)$ & - & $(0.0630)$ \\
\hline \multirow[t]{2}{*}{ Exports (\%GDP) } & 0.00060 & 0.00250 & -0.00360 & $0.00973^{* *}$ & - & 0.03453 & - & $0.18734^{* * *}$ \\
\hline & $(0.0033)$ & $(0.0031)$ & $(0.0070)$ & $(0.0040)$ & - & $(0.0261)$ & - & $(0.0671)$ \\
\hline \multirow[t]{2}{*}{ GDP per Labor (thousands US dollars) } & $0.02410^{* * *}$ & $0.01500^{*}$ & $0.13533^{* * *}$ & $0.09447^{* * *}$ & - & $0.16905^{* * *}$ & - & $0.08423^{* * *}$ \\
\hline & $(0.0086)$ & $(0.0078)$ & $(0.0571)$ & $(0.0068)$ & - & $(0.0221)$ & - & $(0.0309)$ \\
\hline \multirow[t]{2}{*}{$S(1)$} & $0.50762^{*}$ & 0.35175 & 1.36447 & 0.17213 & - & $-5.36689^{*}$ & - & -1.65079 \\
\hline & $(0.3062)$ & $(0.2755)$ & $(0.9201)$ & $(0.4930)$ & - & $(2.9494)$ & - & $(2.8123)$ \\
\hline \multirow[t]{2}{*}{$\mathrm{S}(2)$} & 0.11417 & 0.13525 & $1.04666^{* *}$ & $0.54891 * * *$ & - & -0.16543 & - & $2.77597^{* * *}$ \\
\hline & $(0.1501)$ & $(0.1353)$ & $(0.4899)$ & $(0.1940)$ & - & $(0.6940)$ & - & $(1.0856)$ \\
\hline \multirow[t]{2}{*}{$\mathrm{S}(3)$} & $0.21094^{* *}$ & $0.24935^{* * *}$ & -0.04884 & 0.04000 & - & 0.53132 & - & $0.78072^{* *}$ \\
\hline & $(0.0868)$ & $(0.0828)$ & $(0.3139)$ & $(0.0962)$ & - & $(0.3475)$ & - & $(0.3278)$ \\
\hline \multirow[t]{2}{*}{$\mathrm{S}(4)$} & $0.18996^{* * *}$ & $0.16522^{* * *}$ & $0.50190^{* *}$ & $0.20756^{* * *}$ & - & $0.26694^{* * *}$ & - & $0.96514^{* * *}$ \\
\hline & $(0.0480)$ & $(0.0405)$ & $(0.2120)$ & $(0.0453)$ & - & $(0.0878)$ & - & $(0.1623)$ \\
\hline \multirow[t]{2}{*}{$\mathrm{S}(5)$} & $0.28034^{* * *}$ & $0.21533^{* * *}$ & $0.82924^{* * *}$ & $0.44560^{* * *}$ & - & $0.29364^{* * *}$ & - & $0.76035^{* * *}$ \\
\hline & $(0.0334)$ & $(0.0279)$ & $(0.1563)$ & $(0.0300)$ & - & $(0.0855)$ & - & $(0.0641)$ \\
\hline
\end{tabular}


stages 4 and 5 seems to have a positive and significant influence on the emergence of outward FDI. A one billion US dollar increase in the GDP of neighboring countries at stage 4 of the IDP is expected to increase the probability of the country's transition to stage 3 by $21 \%$, and the same proximity measure for GDP of countries at stage 5 , by $45 \%$, in our RE specification. The fact that coefficients increase in the stage of the neighboring markets is in line with a strong 'spillovers effect'. The positive coefficient on variable $\mathrm{S}(2)$ is equally supportive of the spatial hypotheses. The marginal effect of proximity to markets at stage 2 appears to be double the effect of proximity to countries at higher stages of the IDP, such as stage 4, which is in line with a strong 'foreign market potential' effect. As a general conclusion we can confirm that proximity to countries at higher stages up the IDP has a positive effect on transitions to any stage of the IDP. The magnitude of that impact is generally increasing in the stage of the neighboring markets. It is also noteworthy that spatial lags appear in our results with significantly larger coefficients than other explanatory variables reflecting a country's own market characteristics. The results confirm the importance of a spatial consideration for the analysis of a country's integration in the global FDI network.

\section{Concluding remarks}

The purpose of this paper is to extend the empirical work on the investment development path to incorporate 'space'. The study contributes to an existing literature on the dynamic evolution of the roles of countries as hosts and parents of FDI, where the hypothesis of spatial interrelationships as a determinant of the process is absent. We revise the IDP using the standard international economics framework for the analysis of FDI, and then augment the hypothesis with spatial considerations. The main contribution of our paper lies in the empirical estimation of the importance of spatial determinants for the emergence of inward and outward FDI. Our results suggest that proximity to markets generating FDI increases the probability of a country becoming a 
host, while proximity to these countries and to countries receiving inward FDI increases the probability of receiving FDI. The results are consistent with a number of static spatial hypotheses that have appeared in the literature. More specifically, regarding the emergence of inward FDI in a country, they appear to confirm a 'domestic' as well as a 'neighboring market potential' effect to foreign investors. Empirical predictions for the emergence of outward FDI also appear to give support to a 'foreign market potential effect', and a 'spillovers effect' from foreign investors. Although the literature on the IDP is already large, its study in the context of standard models used in international economics remains poor. Future research on the evolution of a country's roles as host and parent of FDI can therefore take many interesting directions. As a first step, the analysis of the IDP in a general equilibrium context could be used as a basis for the elaboration of alternative mechanisms explaining the process both from a single-country and a spatial perspective.

\section{References}

[1] Bergstrand, J.H. (1985). The Gravity Equation in International Trade: Some Microeconomic Foundations and Empirical Evidence. The Review of Economics and Statistics, 67(3): 474-81

[2] Blomström, M. and R. Lipsey (1991). Firm Size and Foreign Operations of Multinationals. Scandinavian Journal of Economics, 93(1): 101-107

[3] Blonigen, B.A., R.B. Davies, H.T. Naughton, and G.R. Waddell (2008). Spacey Parents: Spatial Autoregressive Patterns in Inbound FDI. in Brakman, S. and H. Garretsen (eds). Foreign Direct Investment and the Multinational Enterprise. Cambridge, MA: MIT Press: 173-197 
[4] Blonigen, B.A., R.B. Davies, H.T. Naughton and G.R. Waddell (2007). FDI in space: Spatial autoregressive relationships in foreign direct investment. European Economic Review, 51(5): 1303-1325.

[5] Braconier, H., P.-J Norbäck, and D. Urban (2005). Multinational Enterprises and Wage Costs: Vertical FDI Revisited. Journal of International Economics, 67(2): 446-70.

[6] Brainard, L. (1997). An Empirical Assessment of the Proximity-Concentration Trade-off between Multinational Sales and Trade. American Economic Review, 87(4): $520-44$

[7] Carr, D., J.R. Markusen, and K.E. Maskus (2001). Estimating the KnowledgeCapital of the Multinational Enterprise. American Economic Review 91(3): 693708.

[8] Caves, R.E. (1974). Causes of Direct Investment: Foreign Firms' shares in Canadian and UK Manufacturing Industries. Review of Economics and Statistics, 56(3): 279293.

[9] Davidson, W.H. (1980). The Location of Foreign Direct Investment Activity, Country Characteristics and Experience Effects. Journal of International Business Studies, 11(2): 9-22

[10] Dunning, J.H. (1981). Explaining the international direct investment position of countries: towards a dynamic or developmental approach. Weltwirtschaftliches Archiv/Review of World Economics, 117(1): 30-64.

[11] Dunning, J.H. (1986). The Investment Development Cycle revisited. Weltwirtschaftliches Archiv/Review of World Economics, 122(4): 667-677. 
[12] Dunning, J.H., and R. Narula (1996). Foreign Direct Investment and Governments. Routledge, London and New York

[13] Durán, J.J., and F. Úbeda (2005). The Investment Development Path of Newly Developed Countries. International Journal of the Economics of Business, 12(1): 123-137.

[14] Ekholm, K., R. Forslid and J. Markusen (2007). Export-Platform Foreign Direct Investment. Journal of the European Economic Association, 5(4):776-795.

[15] Gorynia, M., J. Nowak, and R. Wolniak (2009). Poland's Investment Development Path: in search of a synthesis. International Journal of Economic Policy in Emerging Economies, 2(2): 153 - 174

[16] Görg, H., and D. Greenaway (2004). Much Ado about Nothing? Do domestic firms really benefit from Foreign Direct Investment? The World Bank Research Observer, 19(2): 171-197

[17] Hanson, G., R. Mataloni, and M. Slaughter (2005). Vertical Production Networks in Multinational Firms. Review of Economics and Statistics, 87(4): 664-678.

[18] Helpman, E. (1984). A Simple Theory of International Trade with Multinational Corporations. Journal of Political Economy, 92(3): 451-471.

[19] Hodrick, R.J, and E.C. Prescott (1997). Postwar U.S. Business Cycles: An Empirical Investigation. Journal of Money, Credit and Banking, 29(1): 1-16.

[20] Horstmann, I.J., and J.R. Markusen (1992). Endogenous Market Structures in International Trade. Journal of International Economics, 32(1): 109-129.

[21] Javorcik, B.S. (2004). Does Foreign Direct Investment increase the productivity of domestic firms? In search of spillovers through backward linkages. American Economic Review, 94(3): 605-62 
[22] Markusen, J.R. (1984). Multinationals, Multi-Plant Economies, and the Gains from Trade. Journal of International Economics, 16(3-4): 205-226.

[23] Markusen, J.R. (2002). Multinational Firms and the Theory of International Trade. Cambridge, MA: MIT Press.

[24] Markusen, J.R., and K.E. Maskus (2002). Discriminating among alternative theories of the multinational enterprise. Review of International Economics, 10(4): 694-707.

[25] Markusen, J. R. and A. J. Venables (2000). The Theory of Endowment, Intraindustry and Multi-national Trade. Journal of International Economics, 52(2): 209234 


\section{Appendix}

Data on FDI flows were obtained from the online database of the United Nations Conference on Trade and Development (UNCTAD) ${ }^{4}$. The data set covers 196 economies of the world and provides yearly data on inward and outward FDI flows from 1970 to 2006, in US dollars at 2007 prices. Data on GDP were retrieved from the International Macroeconomic Data Set of the United States Department of Agriculture (USDA) ${ }^{5}$ which provides data for real (adjusted for inflation) GDP, population, real exchange rates, and other variables for 190 countries. The data set covers the period from 1969 to 2006 and data projected to 2017. We used an online conversion calculator ${ }^{6}$ created in conjunction with the Oregon State University Political Science Department ${ }^{7}$, to adjust the series to 2007 prices. The two data sets for FDI and GDP overlap for 187 countries and 37 years (1970-2006) which will be the focus of our analysis. The sample for our analysis consists of 187 countries traced for 37 years; in total 6,919 units of observation. In 1,031 out of these observations, one (or both) values of inward or outward flows is missing from the data. In each of these cases, if there was consistent evidence from years close to the missing observations then the observations were classified by interpolation according to that evidence. Otherwise the observations were classified as 'inconclusive'. 546 of the total observations were excluded from the analysis because of political regimes noncompatible with investment activities, regardless of whether or not observations were missing. The remaining 6,373 observations are used in the empirical analysis undertaken.

\footnotetext{
${ }^{4}$ http://stats.unctad.org/FDI

${ }^{5}$ http://www.ers.usda.gov/Data/Macroeconomics/ According to the documentation attached 'The GDP series starts with the 2000 US dollar GDP series in the latest edition of the World Bank's World Development Indicators and is filled in using other data sources such as Oxford Economic Forecasting, Global Insight, Project Link, and the International Monetary Fund's International Financial Statistics. Conversion to dollars is based on a fixed 2000 exchange rate. Further gaps in all of the data series are filled in by a process of interpolation, extrapolation, or back estimation.'

${ }^{6}$ Columbia Journalism Review http://backissues.cjrarchives.org/resources/inflater .asp

${ }^{7}$ Robert Sahr (Robert.Sahr@orst.edu)
} 